This is the post review version of an article published in the Journal of Environmental Quality.

Arnaud, E., Best, A., Parker, B., Aravena, R., Dunfield, K. 2015. Transport of Escherichia coli through a thick vadose zone. Journal of Environmental Quality, Special Issue on Microbial Fate and Transport in the Subsurface, 44 (5): 1424-1434.

\title{
Transport of Escherichia coli through a thick vadose
}

\section{zone}

\section{Emmanuelle Arnaud, Anna Best, Beth Parker, Ramon Aravena, Kari Dunfield}

E. Arnaud, A. Best and K. Dunfield, School of Environmental Sciences and G360 Centre for Applied

Groundwater Research, University of Guelph, 50 Stone Road, Guelph, Ontario, N1G 2W1, Canada; and B.

L. Parker, School of Engineering and G360 Centre for Applied Groundwater Research, University of Guelph, 50 Stone Road, Guelph, Ontario, N1G 2W1, Canada; and R. Aravena, Department of Earth and Environmental Sciences, University of Waterloo, 200 University Ave. W., Waterloo, Ontario, N2L 3G1, Canada. Received Feb 1st, 2015. Corresponding author (earnaud@uoguelph.ca).

Submitted to: Journal of Environmental Quality (Special section) on Microbial Fate and Transport in the subsurface

Revised and resubmitted: May 6, 2015

Key words: Escherichia coli, fecal bacteria, groundwater, preferential flow, glacial outwash, vadose zone Abbreviations list:

$\mathrm{CFU}=$ colony-forming units 
Highlights

- E. coli detected in groundwater 1 week after manure application

- Underlying bedrock aquifer was contaminated despite a $12 \mathrm{~m}$ thick vadose zone

- Results challenge our understanding of transport and fate in thick unsaturated zone

- Microbial transport to the deep water table suggest active preferential pathways

- Persistent low levels of $E$. coli suggest continued mobilization of bacteria 


\section{Abstract}

Livestock manure applications on fields can be a source of contamination in water resources, including groundwater. Although fecal indicators like Escherichia coli have often been detected in tile drainage systems, few studies have monitored groundwater at depth following manure treatments, especially at sites with a deep, heterogeneous vadose zone. Our hypothesis was that microbial transport through a thick vadose zone would be limited or non-existent due to attenuation processes, and subsurface thickness and heterogeneity. This study tested this hypothesis by monitoring $E$. coli concentrations beneath a 12-meter thick vadose zone of coarse, heterogeneous glacial sediments, following surface application of liquid swine manure. E. coli were detected on all 23 sample dates over the five month period (04/04/2012-13/08/2012), with particularly elevated concentrations one week after application and lasting for five weeks. Variable low-level concentrations both before and after the elevated period suggest remobilization and delayed transport of microorganisms to the water table without additional loadings within the flow field. These findings suggest preferential flow pathways allowing deep infiltration of manure bacteria as well as a continued source of bacteria, with variable retention and travel times, over several months. Preferential flow pathways at this site include soil macropores, depression focussed infiltration, and pathways related to subsurface heterogeneity, and/or fracture flow through finer grained diamict beds. Further research is needed to confirm the relative contribution of sources, constrain travel times and define specific transport pathways. 


\section{Introduction}

Microorganisms such as Escherichia coli (E. coli) and other coliform bacteria are common contaminants in rural domestic wells (Goss et al., 1998). In Canada, there has been wide interest in source water quality and microbial pathogens after an outbreak of E. coli 0157: $\mathrm{H} 7$ and campylobacter in Walkerton, Ontario (Hrudey et al., 2003), was linked to manure-borne pathogen contamination of groundwater. In addition to the risk posed by some pathogenic strains, such as E. coli strain $0157, E$. coli are frequently used as indicators of other fecal contaminants. Large quantities of microorganisms are applied to crop fields within manure or biosolids applications. Although these are traditionally expected to have a low survival rate outside of the host organism (Zaleski et al., 2005), contamination of nearby water resources has often been observed (Unc and Goss, 2004). This can pose a human health risk and is important to address with the modern intensification of livestock agriculture and widespread manure or biosolids application on crops.

The transport of microorganisms from the soil to the saturated zone is mediated by several different processes (Bradford et al., 2013), including physical filtration or film straining, adsorption, and die off related to competition and predation, and unfavourable subsurface conditions (temperature, moisture content, geochemical conditions). These processes are in turn affected by several factors such as land management practices (the timing and type of application, presence of tile drains), hydrodynamic forces, physical and chemical characteristics of the substrate (soil, sediment and bedrock), solution geochemistry, and characteristics of the microorganisms themselves (Unc and Goss, 2003; Oliver et al.,

2005; Bradford et al., 2013). In sum, there are a multitude of factors that make it difficult to predict the fate of microorganisms.

Much research on unsaturated microbial transport and fate has been done with bench scale column experiments (e.g. Gagliardi and Karns, 2000; Bradford et al., 2013; and references therein), with 
comparatively fewer in-situ field studies, which are needed to provide a basis for modelling and predictive attempts (Bradford et al., 2013). In field studies of agricultural settings, bacteria have been observed reaching the depth of tile drainage systems (Dean and Foran, 1992; Oliver et al., 2005; Ball Coelho et al., 2007; Dougherty et al., 2009; Samarajeewa et al., 2012), but monitoring of the vadose zone or groundwater is less common, especially high resolution temporal sampling. Some field research focuses on the risk to shallow bedrock groundwater (Levison and Novakowski, 2009; Samarajeewa et al., 2012), but little work has been done at sites with a thick vadose zone overlying bedrock aquifers.

On the basis of research to date, one of the key factors considered in aquifer vulnerability assessments is the thickness and nature of the materials that overlie the water table. The assumption is that a relatively thick overburden will provide sufficient protection to the underlying aquifer. Straining, retention or die off during transport is more likely to occur the longer the pathway is to the water table. Interestingly, there are no guidelines as to what constitute a thick enough overburden to maximize protection of underlying aquifers, yet many would hypothesize that a $10+m$ vadose zone would likely provide adequate protection from microbial contamination, since unsaturated conditions are thought to be more conducive to retention (Bradford et al., 2013).

The Arkell Research Station (ARS) is an agricultural research facility near the city of Guelph that is located on an outwash plain with $12 \mathrm{~m}$ of glacial sediments overlying a fractured Silurian dolostone aquifer. The water table at the site is found at $13 \mathrm{~m}$ below ground surface. As part of a larger study on non-point source pollutants in agricultural settings (Best et al., 2015), a preliminary study was carried out to test the hypothesis that $10+m$ would be thick enough to mitigate any potential microbial contamination from a manure application. E. coli and total coliforms in groundwater were monitored at the site before and after a spring manure application over a period of five months, to investigate the transport and fate of fecal indicators at this site. 


\section{Study area}

The Arkell Research Station is a 200 ha research facility (Fig. 1) operated by the University of Guelph since 1967. It includes cropped fields on a corn-corn-soybean-wheat rotation with a long history of manure applications, and houses cattle, pigs, horses, chickens and turkeys. The site is conventionally tilled by mouldboard ploughing two out of the four years of rotation (and including the study period 2011-2012) and receives chemical fertilizer and manure applications once or more per year with a typical manure application rate of 45,800 to 60,500 L/ha between 2001 and 2012. Additions are determined using a nutrient management plan under the Ontario 2002 Nutrient Management Act for appropriate input levels balanced by the nutrient removal through crop harvest. The manure is liquid swine, and is surface applied by tanker after tillage by discing, and incorporated (into the soil) within several days.

The multilevel well for this study was installed near the eastern edge of the station (Fig. 1), immediately downgradient of field A5, with short depth-interval sampling improving detection capability. Field A5 is 32 ha in size with gently rolling topography and swales (Fig. 1, Fig. S1). The soil series is Burford Loam (Wagner-Riddle and Thurtell, 1998), which is a well-drained Grey-Brown Luvisol that forms on stratified gravel deposits varying in size from fine sand to cobbles (Presant and Wicklund, 1971). The water table is positioned in the top of the bedrock, approximately $13 \mathrm{~m}$ below surface during the study period. There is a very low potential for runoff given the relatively flat topography at the scale of the manure application. There is also no artificial drainage and no runoff collection ditches surrounding or within the field. During the 2011-2012 study period, corn was grown and manure was applied to the whole field (32 ha) in Fall 2011 at a rate of 60,500 L/ha. Manure was applied again in Spring 2012 to a small (1.6 ha) area next to the multilevel ARS-1A at a rate of 61,700 L/ha (Fig. 1). While wildlife has been documented as a potential source of E. coli in other studies (Somarelli et al., 2007; Gallagher, 2012), no wildlife scat 
has been observed on site during this study or in years prior (Peter Milton, pers. comm. 2015), such that the only source of $E$. coli on the field is from the annual application of manure.

The study site is situated on a glaciofluvial outwash plain, adjacent to the frontslope of the Paris Moraine (Karrow, 1968, 1987) and underlain by Silurian dolostone of the Guelph Formation. The Guelph Formation is a shallow, unconfined bedrock aquifer used by some nearby domestic well owners and one municipal well. The regional groundwater flow is primarily downward (Gartner Lee, 2004) through the unconsolidated glacial sediments and fractured sedimentary rock due to pumping. Lateral flow occurs in the shallow unconfined bedrock aquifer due to contrasts in hydraulic conductivity, enhanced along bedding in some bedrock units. Lateral flow is towards the south regionally (Gartner Lee, 2004), but towards the North to the Eramosa River and the municipal well in the area surrounding the study site (Opazo Gonzalez, 2012). Localized lateral flow also occurs in the unconsolidated sediments where finergrained glacial materials impede downward flow (Best et al., 2015). In previous studies on site, a network of 18 piezometers was installed across the station in the base of the unconsolidated glacial outwash sediments and in the upper, Silurian dolostone bedrock. These have been used to estimate the position of the water table and local direction of groundwater flow (Opazo Gonzalez, 2012) (Fig. 1).

Farther upgradient of field $\mathrm{A} 5$ are a mix of other farms and forested areas on the relatively high relief and hummocky Paris Moraine. Any potential groundwater and contaminants coming from farther upgradient on the moraine would be forced by ongoing recharge to move downward and deeper in the system below the monitoring ports in this study. Considering the site's glacial setting (outwash plain next to the hummocky moraine), topography (lack of any surface drainage from the site and steep frontslope and closed depressions of the moraine) and the groundwater flow direction, we infer that manure applications on field $\mathrm{A} 5$ are the only possible source of impact on water quality that will be 
detected in the ARS-1A monitoring well. This is further supported using the Harter et al. (2002) geometric approximation of source area:

$L=d_{\mathrm{MW}}{ }^{*} q / R$

Where $L$ is the is the linear upgradient distance of the contamination source zone; $d_{\mathrm{MW}}$ is the depth of monitoring interval below the water table $(2.29 \mathrm{~m}) ; q$ is the average groundwater discharge rate $(2.3 \times 10$ ${ }^{-8} \mathrm{~m} / \mathrm{s}$ ) based on horizontal gradient measured on site $(0.0045)$ and hydraulic conductivity estimates $(5.0$ $\times 10^{-6} \mathrm{~m} / \mathrm{s}$ ) from short interval tests in the same rock unit at a nearby Guelph site (Belan, 2010; Quinn et al., 2011); and $R$ is the net recharge rate $(300 \mathrm{~mm} / \mathrm{yr})$ in the source area based on estimates for Guelph (Brown et al., 2013). Based on these values, the linear upgradient distance of the monitoring well's contamination source zone is $5.5 \mathrm{~m}$. This would increase to $54 \mathrm{~m}$ if the highest hydraulic conductivity $\left(5.0 \times 10^{-5} \mathrm{~m} / \mathrm{s}\right.$; Gartner Lee Ltd., 2004), highest horizontal gradient (0.0045 measured between October 2011 and August 2012; Opazo Gonzalez, 2012) and lowest recharge rate estimates (155 mm/yr; Brown et al., 2013) are used. While certain assumptions such as spatially and temporally constant recharge and flow rates, and unidirectional groundwater flow are made (Harter et al., 2002), the estimated contamination source zone is well within the confines of field A5 and the 1.6 ha area $(210 \times 75 \mathrm{~m}$ field dimensions and $115 \mathrm{~m}$ between ARS-1A and the outer edge of the field in the upgradient groundwater flow direction) where manure was applied in 2012.

The network of piezometers on site has been used to monitor water quality since the 1980 s. Since as early as 1980, the local groundwater has had historically elevated nitrate concentrations, likely arising from on-site manure and fertilizer applications (H.R. Whiteley, personal communication, 2013; Opazo Gonzalez, 2012; Best et al., 2015). Bacterial movement by macropore flow within the soil profile has been observed on site (Unc, 1999). However, microbial contamination at depth in relation to a specific manure application event has never specifically been investigated. 


\section{Methods}

\subsection{Initial field activities}

A continuous core was recovered using rotosonic drilling $3 \mathrm{~m}$ into bedrock ( $15 \mathrm{~m}$ total depth) and logged in detail on September 18, 2011. A multilevel well (ARS-1A) was installed the next day with ports aligned with specific sedimentological and inferred hydrologic properties. Prior to this date, manure had been applied to the eastern half of field A5 (Fig. 1) in August 2011, but the side adjacent to the drill site was avoided until after well installation was completed to avoid contamination of the subsurface during

drilling. Sediment cores were described in detail (cm scale) noting changes in texture, colour, sorting, sedimentary structures, and clast characteristics such as average and maximum size, roundness and mineralogy. Bedrock cores were similarly described in detail noting in addition presence of fractures and evidence of chemical alteration or staining around those fractures. The multilevel well is a 7-port Solinst Continuous Multichannel Tubing (CMT) well (Einarson and Cherry, 2002), with sand (size \#40) backfilled around the monitoring zones and coated bentonite tablets or bentonite holeplug chips (Enviroplug) backfilled as seals between monitoring zones and above the top monitoring zone to the surface. Fractured zones of the bedrock, and unconsolidated sediment zones of different lithologies, which may act as aquifers or aquitards, were targeted when locating monitoring intervals in order to capture any perched water conditions or changes in hydraulic conditions. This system allows groundwater sampling and monitoring of specific hydraulic conditions at discrete depths to minimize blending. During this study, water was obtained only from the deepest two ports, located in the bedrock, whereas the others remained dry. 
Water depths were measured manually, approximately weekly or more frequently when sampling was undertaken, with a Skinny Dipper water meter (Heron Instruments Inc., Dundas, Ontario) and recorded to the nearest $0.03 \mathrm{~m}$. Elevation at the top of the well was obtained using a Leica Diva GPS with $1 \mathrm{~cm}$ accuracy. Precipitation data for the study period were obtained from the nearby Guelph Turfgrass Institute weather station 4.5 kilometers away (Agricultural and Forest Meteorology Group, 2012).

\subsection{Microbiological sampling methods}

Field sampling of soil, manure and groundwater for microbiological analyses was undertaken from April 4 to August 13, 2012. To determine background microbial loading in the soil, three soil samples of $300 \mathrm{~g}$ each were taken from the study field approximately $50 \mathrm{~m}$ apart prior to manure application. These were taken from the top $15 \mathrm{~cm}$ of the soil with a trowel cleaned with $70 \%$ ethanol solution before and between sampling, and stored in Ziploc bags on ice until transferred to a $4^{\circ} \mathrm{C}$ cooler. Subsamples of soil were oven-dried to determine soil moisture content.

Liquid swine manure, sourced onsite at the Arkell Research Station from an open topped circular tank, was agitated and surface applied by tanker on April 9, 2012. The field had been pre-tilled April 5 and incorporation of the manure was performed in the two days following application. Triplicate manure samples were obtained directly from the tanker after application on April 9. These were kept in sterile polyethylene bottles on ice until transferred to a $4^{\circ} \mathrm{C}$ cooler.

The deepest two ports, located below the water table, were sampled during the study period (04/04/2012 - 13/08/2012). Two groundwater sampling events were carried out in the week prior to application. After the application, water samples were taken repeatedly at a rate of two or three times per week in the first four weeks, then once every one to three weeks, for a total of 23 sampling events. Water samples were taken from the well ports using Teflon coated sample tubing and a peristaltic pump. Due to the deep water table, water could not be pumped continuously to the ground surface. 
Instead, water was pumped as far as possible into the tubing; the tubing was then pulled up from the well to allow discharging of the water inside it. The lower $2.5 \mathrm{~m}$ of tubing that came into contact with the groundwater in the well was kept inside the well to avoid ground surface contamination. This process was repeated until adequate volumes were recovered. The outer surface was cleaned with $70 \%$ ethanol before insertion into the well and any time it was removed. Before sampling from each port, two liters of deionized water were flushed through the sample tubing, and at least three "well" volumes were purged from the port to remove stagnant well water and to again flush the sample tubing and avoid cross-contamination. Sampled water was kept in a sterile 500 to $1000 \mathrm{ml}$ high-density polyethylene bottle on ice until transferred to a $4^{\circ} \mathrm{C}$ cooler at the completion of the sampling event. Additional groundwater samples for isotopic analysis (tritium) were collected from each port, following a similar procedure, on May 14, 2012.

\subsection{Microbiological Sample analysis}

Water samples were analyzed for total coliforms and undifferentiated $E$. coli using vacuum filtration (EPA, 2002) within 24 hours of sampling. Each water sample was run in triplicate. For each triplicate, $100 \mathrm{ml}$ of sample water were filtered through a sterile, $47 \mathrm{~mm}, 0.45 \mu \mathrm{m}$ mixed cellulose ester membrane filter (Fisher Scientific) and transferred aseptically to petri plates containing Oxoid CM1038 differential coliform agar. Soil and liquid manure samples were serially diluted with sterile phosphate buffered saline solution and spread-plated (Buck and Cleverdon, 1960) on Oxoid CM1038 differential coliform agar. All plates were incubated at $35^{\circ} \mathrm{C}$ for 24 hours before total coliforms were counted and for 48 hours before E. coli was counted. Total coliform colonies appeared pink and E. coli appeared blue on the agar plate. Final values are reported as colony-forming units (CFU) per gram of dry soil and per $100 \mathrm{ml}$ of equivalent porewater (soil samples), CFU per $100 \mathrm{ml}$ manure and per g dry manure matter (liquid manure samples), and CFU per $100 \mathrm{ml}$ (water samples). 


\subsection{Other sample analyses}

Particle size analysis of sediment samples was carried out using sand sieving and a hydrometer following the methods of Kroetsch and Wang (2008); the relative \% of gravel-sized particles was visually estimated in the field. Additional groundwater samples were analyzed for tritium by the University of Waterloo Environmental Isotope Laboratory using enrichment by electrolysis and liquid scintillation counting (Taylor, 1977; Packard Instrument Company Inc., 1986). Results are reported in tritium units (TU), with a method detection limit of $0.8 \mathrm{TU}$ and a standard deviation of the mean of 0.3 to $1.5 \mathrm{TU}$.

Statistical analyses were performed using RStudio environment for R (R Development Core Team, 2014; RStudio, 2014). To determine whether there were significant changes in the $E$. coli concentration of each port over time, a one-way analysis of variance was performed. For each port, water sample data was grouped by sample date, where each date contained three laboratory replicate concentrations. The data were not normally distributed, so non-parametric analyses of variance, the Kruskal-Wallis test, was used. One test assessed whether the differences between the median E. coli concentrations on each date were greater than would be expected by random chance, whereas a second test was used to compare the background periods and the "elevated" period. The concentrations used for the second test were the means of the three replicates from each port for each date. Post-hoc testing to identify concentration differences between dates was also carried out.

To test the effects of precipitation on the bacterial flux, E. coli concentrations in each port were compared with total rainfall (Agricultural and Forest Meteorology Group, 2012) in the 24, 48, 72, 96, and 120 hours prior to sampling using a linear regression. This analysis was repeated using a subset of the data pertaining to the period of elevated E. coli concentrations.

\section{Results}




\subsection{Geological characteristics}

The continuous sediment core was composed of gravel and diamict (a mixture of clay, silt, sand and < 50\% gravel) layers with variable matrix grain size distribution and gravel-sized clast content (Fig. 2). The loamy soil extended to $0.8 \mathrm{~m}$ below ground surface (bgs) and graded into an upper unit of crudely layered, poorly sorted gravel extending down-core to $6.5 \mathrm{~m}$ bgs. The layering within the gravel was defined by variations in colour, moisture content, as well as clast size and abundance relative to the silty sand matrix. A sandy diamict unit was observed from 6.5 to $7.0 \mathrm{~m}$ bgs, distinguishable by its lower concentrations of gravel sized clasts relative to the above gravel and lower mud content and lesser cohesion relative to the underlying diamict. The lowermost unit of cohesive, intermediate diamict from 7.0 to $11.6 \mathrm{~m}$ bgs, included a $0.45 \mathrm{~m}$ bed of poorly-sorted gravel (Fig. 2). Paleozoic Guelph Formation dolostone bedrock was present from $11.6 \mathrm{~m}$ bgs to the bottom of the hole at $15.2 \mathrm{~m}$. Multiple fractures were observed in the bedrock core, with iron oxide staining suggesting water flow in six horizontal fractures. One $0.6 \mathrm{~m}$ section, from 13.1 to $13.7 \mathrm{~m}$ bgs, contained multiple subvertical fractures, with some of the fractures also exhibiting iron staining.

Graphic logs drawn using cuttings recovered during the 1980 piezometer installation (H.R. Whiteley, personal communication, 2013) were used along with the ARS-1A core to produce a geologic crosssection through the station (Figs. 1 and 3). Although classifications are broad and there is some uncertainty in the distinction between diamict and sandy gravel especially when logging from cuttings, this cross-section provides some geologic context for the site. At surface, sediments are typically sand and gravel, with some occurrence of mud or diamict. At depth, there is often a basal diamict present, but this appears to be discontinuous (Fig. 3). A ground penetrating radar (GPR) survey carried out nearby on the front slope of the moraine (Fig. 1) was interpreted as showing stacked layers of sediment laid down by debris flows or water flows, sometimes interrupted by channelized flows, overlying a more homogeneous layer interpreted to be till (Sadura et al., 2006). The sand and gravel at ground surface 
throughout the Arkell Research Station is thought to be deposited by meltwater emanating from the ice margin (Karrow, 1968, 1987).

\subsection{Hydrological and hydrogeological characteristics}

The 2012 winter was unusually warm and dry, with consequently minimal spring snowmelt. The 2012 spring and summer seasons were also characterized by lower than normal precipitation in April, May and July (Environment Canada, 2013). Precipitation events prior to manure application included a 1.6 $\mathrm{mm}$ and $0.2 \mathrm{~mm}$ event, eight and seven days before manure was applied on April 9, 2012. Another 3.4 $\mathrm{mm}$ of rain fell on site on April 15, 2012 before the first spike in E. coli concentrations was observed on April $16^{\text {th }}$. The remainder of the sampling period is characterized by precipitation events ranging from $0.2 \mathrm{~mm}$ to a high of $37.6 \mathrm{~mm}$ (August 11) interspersed with multiple one to twelve day long periods with no precipitation.

Hydraulic conductivity $\left(K_{\text {sat }}\right)$ estimates using grain size distributions of the gravel and intermediate diamict range from $10^{-5}$ to $10^{-6} \mathrm{~m} / \mathrm{s}$ (Fig. 2; using the SPAW computer model of Saxton and Willey, 2005; Saxton and Rawls, 2006; Saxton, 2007). While the $K_{\text {sat }}$ value for the diamict may appear to be high, it is consistent with the coarse-grained matrix and clast-rich nature of this diamict as well as with published ranges of hydraulic conductivities for glacial till (Freeze and Cherry, 1979). At surface, $\mathrm{K}_{\text {sat }}$ was estimated to be $4.1 \times 10^{-6} \mathrm{~m} / \mathrm{s}$ using a double ring infiltrometer (unpublished data, pers. comm. J. Levison, 2015). The water table was deep, at 12.9 to 13.2 meters below surface during the study period. Water was present only in port 6 and 7 and had a slight downward gradient ( 0.06 on average) between these two monitoring zones. A bedrock corehole $500 \mathrm{~m}$ away (UG-01, Fig. 1) showed transmissivity of $0.1 \mathrm{~cm}^{2} / \mathrm{s}$ where it was measured in the Guelph Formation (Opazo Gonzalez, 2012). Another corehole, located in a similar setting $2 \mathrm{~km}$ to the northeast, exhibited transmissivity of $3-6 \mathrm{~cm}^{2} / \mathrm{s}$ in the lower Guelph Formation, while the upper Guelph Formation was so transmissive that FLUTe profiling data could not 
be recovered (Opazo Gonzalez, 2012). Although no hydraulic testing was performed in ARS-1A, about 3700 litres of drilling water were quickly lost in the top meter of bedrock during drilling, suggesting rapid fracture flow in the upper, unsaturated bedrock. Tritium concentrations of 19.1 and 19.7 TU in water samples from ARS-1A indicate that the water is within the range of modern precipitation samples (AECOM, 2009; Camillo, 2013).

\subsection{Microbiological characteristics}

Field soil collected on April 8, 2012 (prior to the April 9 manure application) contained $3.8 \times 10^{3} \pm 8.9 \times$ $10^{2}$ (SE) CFU/g E. coli (Table 1), showing a clear presence of these indicators even with no manure applications since September 2011. The sample of liquid swine manure contained $4.6 \times 10^{4} \pm 1.1 \times 10^{4}$ CFU / $100 \mathrm{ml}$ E. coli.

E. coli were detectable in all groundwater samples over the five month period both before and after the manure treatment (Fig. 4). Samples taken before the manure treatment contained $30 \pm 7$ (SE) to $56 \pm 1$ $\mathrm{CFU} / 100 \mathrm{ml}$. Following the manure treatment, the $E$. coli concentrations exhibited a five to six week long period of "elevated" concentrations ranging up to the upper detection limit of $300 \mathrm{CFU} / 100 \mathrm{ml}$. Low "background" levels within one order of magnitude were otherwise observed after the "elevated" period, with typical concentrations of less than $60 \mathrm{CFU} / 100 \mathrm{ml}$, consistent with the levels detected before the manure application. One exception to this "background level" period was detected on July 20, 102 days after the manure was applied with concentrations of $109 \pm 6 \mathrm{CFU} / 100 \mathrm{ml}$ in port 6 and 111 \pm 4 CFU/100ml in port 7. The period of "elevated" levels begins between Apr. 13 and 16, one week or less after the manure treatment, and ends between May 14 and 23, five to six weeks after the treatment. This elevated concentration is more pronounced in Port 7, as there were several dates with low concentrations observed in Port 6 during this time period. 
Total coliforms (besides E. coli) were rarely detected, and counts were below $5 \mathrm{CFU} / 100 \mathrm{ml}$ when present, so no further analysis of the data was performed for total coliforms. The low counts could have resulted from competition with other microorganisms (LeChevallier and McFeters, 1985). Unidentified heterotrophic bacteria, which appeared clear or white, were present on all plates.

On the basis of the first Kruskal-Wallis test, there were significant differences among the median E. coli concentrations over the sample dates ( $p$-value $<0.0001$ ) for port 6 and for port 7 , indicating that there were significant changes in the $E$. coli concentrations over the study period, which are not accounted for by the variations within each water sample. The second test comparing the "background" period (April 4 to April 13 and May 23 to August 13) and "elevated" period (April 16 to May 14) for each port found significant ( $p$-value $<0.01$ ) differences among the median $E$. coli concentrations for the two time periods for the two ports. The post-hoc test showed a significant difference between the "background" and "elevated" time periods for port 7 ( $p$-value $<0.01)$ and for port $6(p$-value $<0.1)$. Post-hoc testing of Port 6 data to identify concentration differences between all dates revealed significant difference ( $p$ value $<0.05$ ) between the high spike date of Apr. 16, against three particularly low concentrations on the following dates: Apr. 11 (post-application, before spike), Apr. 23 (one of the low concentrations within the elevated period), and June 4 (low concentration in the background period after the elevated period; Fig. 4b). Similar testing of Port 7 data revealed significant differences ( $p$-value $<0.05$ ) between the two high spike dates of Apr. 16 and 28 and June 4 (Fig. 4b).

There was no significant relationship between rainfall and port $7 \mathrm{E}$. coli when including the entire study period, or between rainfall and port 6 E. coli in the overall or elevated time period. Two significant relationships existed ( $p$-value $<0.05)$ : port 7 samples from the elevated period were negatively correlated with both 72 -hour precipitation ( $R^{2}$ value 0.45$)$ and with 96-hour precipitation $\left(R^{2}\right.$ value 0.44$)$. These negative relationships could be a result of precipitation diluting bacterial concentrations, but 
given the relatively weak correlation and limited amount of data, as well as the dampening effect of the thick unsaturated zone, it appears that there is no obvious direct effect of precipitation on groundwater bacterial levels at this site. Although precipitation is commonly thought to drive transport of bacteria in the subsurface, the role of other factors in contributing to the ultimate fate of microbial contaminants is often emphasized (Unc and Goss, 2004; Bradford et al., 2013). The lack of relationship with rainfall here suggests that those other factors are important in determining the ultimate distribution of contaminants at depth and their arrival time at the water table.

\section{Discussion}

The goal of this study was to test the hypothesis that a $10+m$ thick vadose zone would provide the underlying bedrock aquifer adequate protection from microbial contamination and to investigate the transport and fate of $E$. coli in this coarse-grained glacial outwash setting. Results show that $E$. coli has reached the water table despite the thick vadose zone and that concentrations vary significantly over time. Although concentrations are variable between sample dates, a common observation in groundwater studies (Levison and Novakowski, 2009; Vanderzaag et al., 2010; Kozuskanich et al., 2011), there is a time frame of particularly elevated concentrations beginning one week after the manure application and continuing for one month.

\subsection{Preferential flow paths in a thick vadose zone}

Considering surficial manure applications as the most likely source of elevated $E$. coli concentrations (as discussed in section 2), manure or bacteria-contaminated water infiltrated the $13 \mathrm{~m}$ thick unsaturated zone to reach the groundwater some time after application (Fig. 5). Using sediment texture of the ARS$1 \mathrm{~A}$ continuous core, the field capacity moisture content of each sediment layer was estimated using the SPAW (Soil-Plant-Air-Water) modelling program (Saxton and Willey, 2005; Saxton and Rawls, 2006; 
Saxton, 2007). Using a depth-averaged moisture content value (19.4\%) and average infiltration rate for Guelph (308 mm/year; Fallow et al., 2003), the equation for unsaturated zone advection time (UZAT) (Technical Experts Committee, 2004) was used to estimate the average time of travel for bulk matrix water to move from the surface at ARS-1A to the top of the bedrock (11.6 m).

UZAT [years] $=($ depth $[\mathrm{mm}] \times$ soil water content $[\%]) /$ infiltration rate $[\mathrm{mm} / \mathrm{yr}])$

The bulk matrix water would take seven years to travel through the ARS-1A sediment profile, or almost four years if the sediment was entirely composed of the coarsest material encountered in the core. If water moved through the unsaturated zone by uniform, plug flow, a much greater amount of filtration and die-off would be expected over this time resulting in more consistent, lower, or non-detectable $E$. coli concentrations. Thus, preferential pathways enabling faster transport of contaminated water from the surface must be present to produce the elevated concentrations of $E$. coli found in this study. These pathways likely result from 1) macropores in the soil profile (Jarvis, 2007), 2) sediment heterogeneity at depth, 3) fractures within relatively finer-grained sediments on site, 4) the broad swales on site generating depression-focussed infiltration and 5) fractures in the underlying bedrock (Fig. 5).

Macropore transport of fecal bacteria has been observed at the Arkell Research Station to a depth of $0.75 \mathrm{~m}$, and this macropore flow can be initiated by as little as $2 \mathrm{~mm}$ of precipitation (Unc, 1999). In the current study, the volume of manure applied was an equivalent of $6 \mathrm{~mm}$ of precipitation, and the first spike in E. coli concentration occurred one week later after an additional $3.4 \mathrm{~mm}$ rainfall. These additions of water would promote the downward movement of manure bacteria through the existing macropores (Unc and Goss, 2003).

Below the $\mathrm{C}$ Horizon of the soil profile, sediment heterogeneity within the parent material was likely a major control on deeper infiltration (Best et al., 2015). The site is situated on spatially heterogeneous glaciofluvial deposits (Fig. 3) adjacent to the outwash fan of the Paris Moraine (Karrow, 1968, 1987; 
Sadura et al., 2006). While straining can promote retention, interconnected permeable units and discontinuous basal diamict (Fig. 3) can function as preferential flow paths (Sminchak et al., 1996; Anderson et al., 1999; Iversen et al., 2008). The discontinuous diamict can be attributed to meltwater erosion of the basal diamict during ice retreat, a phenomenon that is likely to occur elsewhere in other glacial outwash settings.

Preferential transport of $E$. coli may also be attributed to fracture flow within the diamict where it is present. Surficial diamict with clay content ranging from 10 to $45 \%$ can exhibit fracturing up to 4 to 11 m depth (Ruland et al., 1989; Mckay et al., 1993; Harrar et al., 2007) and these may not be visible to the naked eye or intercepted by core drilling (Ruland et al., 1989). Fracturing has also been observed in buried diamict (Gerber et al., 2001; Meriano and Eyles, 2003). Fractures may exist on site at depth considering the glacial history of the study site (Karrow, 1968, 1987), the clay content of the basal diamict (Fig. 2; clay fraction of 10-23\%) and its thickness ( $3 \mathrm{~m}$ ), though further study is needed to confirm the role of this process in affecting microbial transport.

Another phenomenon that may have enhanced the infiltration of colloids is depression-focused recharge. This has been observed elsewhere on a wide range of scales, from micro-topographical elevation differences (cm scale) (Schuh et al., 1993) to large scale depressions (tens to $100 \mathrm{~m}$ wide with meter-scale depth) (Derby and Knighton, 2001; Gerke et al., 2010). The study field is gently rolling with small hills and swales; one such depression (10s of $\mathrm{m}$ scale) is located at the edge of the manure-applied area (Fig. S1). This depression has been observed to have damp soil with visible mud cracks where the surrounding area of the field is relatively coarse-textured and dry, suggesting a greater amount of temporary ponding, infiltration, and higher water content increasing the permeability to water after precipitation events. Depression-focused recharge may then have affected the distribution of the liquid 
manure load and of water during later rainfall events, and may have contributed to a faster than expected and spatially variable downward migration of both groundwater and colloids.

Upon reaching the unsaturated bedrock surrounding the ARS-1A well, infiltrating water would move relatively quickly through fractures in the rock (Borchardt et al., 2007). This is supported by the visual identification of fractures with staining indicative of active water flow in the core, high transmissivity values measured in a nearby bedrock well (UG-01, Fig. 1) (Opazo Gonzalez, 2012), and the loss of drilling water at this depth during drilling of ARS-1A. The very similar pattern of $E$. coli concentrations in the two ports also suggests rapid velocities and connectivity through fractures between these two bedrock depths.

\subsection{Contamination of a thick vadose zone}

Populations of $E$. coli were found in the field soil and in the groundwater before the manure application in April 2012. With the preceding manure application in field A5 occurring in August and September 2011, these populations could have survived over eight months in the soil. E. coli has been observed to survive in soil for at least four months, and even replicate there (Oliver et al., 2005; Zaleski et al., 2005; Lang and Smith, 2007; Brennan et al., 2010), thus becoming "naturalized" (Ishii et al., 2006). The high nutrient and carbon content of the agricultural soil may provide a good environment for survival or replication and bacteria are known to survive relatively low temperatures typical of groundwater (Vanderzaag et al., 2010). Once naturalized, these microorganisms would be released from the vadose zone over time (e.g. Dougherty et al., 2009) as a result of sediment (Fig. 2, 3, 5) and geochemical (Best et al., 2015) heterogeneity in the subsurface, as well as transient water saturation associated with intermittent precipitation events. This would provide a "background" supply of microbiological contaminants to the underlying aquifer. 
The isolated peak in late July that interrupts a period of otherwise low concentrations of $E$. coli suggests remobilization and delayed transport of colloids to the groundwater table. This can be attributed in part to the observed sediment heterogeneity at depth, whereby colloids would take various flow paths with different physical and chemical subsurface conditions that would result in transient water saturation, hydrodynamic forces and variable solution chemistry, and repeated adsorption and detachment (Fig. 5). This would ultimately lead to variable travel times and intermittent release to the water table following an initial manure application.

The timing of the "elevated" period of E. coli concentrations a week following the manure application of April 9, 2012 can be explained by either 1) rapid transport of contaminated water through the thick vadose zone or 2) release and delivery of contaminated water to the water table with bacteria coming over time from any or all of the naturalized populations within the soil, the 2011 and/or 2012 manure treatment. We cannot rule out a contribution of some pre-existing $E$. coli from the vadose zone. However, rapid transport of the large influx of contaminated water applied on April 9, 2012 is certainly plausible considering the preferential flow paths identified on site, the relatively short linear distance of the source zone and the strong temporal association between the date of application and the statistically significant "elevated" period. Rapid transport of the contaminated water with a slight delay in arrival time followed by a variable but statistically significant elevated period of E. coli concentration would also be the simplest explanation based on Ockham's Law of Parsimony (Ockham's razor), which favours the simpler of two competing hypotheses. In the end, the study as originally designed is not able to discriminate between these scenarios. Additional microbial and hydraulic data is needed to identify the relative contribution of these sources and to better constrain the travel times to the water table.

\subsection{Conclusion}


Often, die-off or retention is considered to be highly effective, and research is focussed on areas with a thin, less protective vadose zone. However, it is clear from this study that fecal bacteria can contaminate aquifers overlain with over 10 metres of unsaturated sediments. The results also suggest that preferential flow paths and remobilization of bacteria at least three months after a treatment can be significant, and that a basal diamict expected to slow infiltration and increase retention did not appear to have this effect. Remobilization associated with transient water flow conditions in the unsaturated zone, the local subsurface geology, variable recharge, and the poorly understood nature of microbial transport and fate in unsaturated zones will make it difficult to predict time of travel and loading to nearby wells, making regular well monitoring and water testing important. Once in the bedrock aquifer, rapid transport and far-reaching contamination through the fractured dolostone is expected (Borchardt et al., 2007). Future monitoring at this site with higher temporal and spatial resolution, along with vadose zone and hydraulic characterization, will help identify specific active pathways and travel times, relative contributions of sources and most significant factors controlling microbial transport in the subsurface. 


\section{Acknowledgements}

This study was primarily funded through the Ontario Ministry of Agriculture and Rural Affairs-University of Guelph Partnership (Environmental Sustainability theme). The Natural Sciences and Engineering Research Council, the Ontario Research Fund-Research Excellence and the Geological Survey of Canada, as well as in-kind contributions from Solinst Canada Ltd. provided additional financial support. We are grateful for site access provided by the University of Guelph and assistance kindly given by the staff at the Arkell Research Station. We also acknowledge helpful discussions with Gary Parkin and the field and lab assistance from staff and students of G360 Centre for Applied Groundwater Research and the School of Environmental Sciences.

\section{Supplemental Material}

Fig. S1: Photo showing the topography in Field A5 that is contributing to depression-focused infiltration. 


\section{References}

AECOM. 2009. Arkell Springs Grounds Hydrogeologic Study. Prepared for the City of Guelph.

Agricultural and Forest Meteorology Group. 2012. Weather Records for the Guelph Turfgrass Institute, Guelph, Ontario [Canada]: Meteorological data 2012. Guelph Turfgrass Institute, AgriEnvironmental Res. Data Repos. [Distributor] V6 [Version]. Available at http://hdl.handle.net/10864/RSVM4.

Anderson, M.P., J.S. Aiken, E.K. Webb, and D.M. Mickelson. 1999. Sedimentology and hydrogeology of two braided stream deposits. Sediment. Geol. 129(3-4): 187-199.

Ball Coelho, B.R., R.C. Roy, E. Topp, and D.R. Lapen. 2007. Tile water quality following liquid swine manure application into standing corn. J. Environ. Qual. 36(2): 580-7.

Belan, K. 2010. Characterizing a fractured rock aquifer with hydraulic testing at a contaminated municipal well using flexible liner methods and depth discrete monitoring. M.ASc. thesis, University of Guelph, School of Engineering.

Best, A., E. Arnaud, B. Parker, R. Aravena, and K. Dunfield. 2015. Effects of glacial sediment type and land use on nitrate patterns in groundwater. Ground Water Monit. Remediat. 35(1): 68-81.

Borchardt, M.A., K.R. Bradbury, M.B. Gotkowitz, J.A. Cherry, and B.L. Parker. 2007. Human enteric viruses in groundwater from a confined bedrock aquifer. Environ. Sci. Technol. 41(18): 6606-6612.

Bradford, S.A., V.L. Morales, W. Zhang, R.W. Harvey, A.I. Packman, A. Mohanram, and C. Welty. 2013. Transport and fate of microbial pathogens in agricultural settings. Crit. Rev. Environ. Sci. Technol. 43: 775-893.

Brennan, F.P., V. O'Flaherty, G. Kramers, J. Grant, and K.G. Richards. 2010. Long-term persistence and leaching of Escherichia coli in temperate maritime soils. Appl. Environ. Microbiol. 76(5): 1449-55.

Brown, D.M., H. Dadfar, D.J. Fallow, R.J. Gordon, J.D. Lauzon, and G.W. Parkin. 2013. Temporal and spatial variability of water surplus in Ontario, Canada. ISRN Soil Sci. 2013. Available: http://dx.doi.org/10.1155/2013/362895 [Accessed 27 April, 2015].

Buck, J.D., and R.C. Cleverdon. 1960. The spread plate as a method for the enumeration of marine bacteria. Limnol. Oceanogr. 5(1): 78-80.

Camillo, J. 2013. Application of the discrete fracture network approach to characterize bedrock aquifer contamination at a former dry cleaner site. M.Sc. thesis, University of Waterloo.

Dean, D., and M. Foran. 1992. The effect of farm liquid waste application on tile drainage. J. Soil Water Conserv. 47(5): 368-369. 
Derby, N.E., and R.E. Knighton. 2001. Field-scale preferential transport of water and chloride tracer by depression-focused recharge. J. Environ. Qual. 30: 194-199.

Dougherty, M.C., N. V. Thevathasan, A.M. Gordon, H. Lee, and J. Kort. 2009. Nitrate and Escherichia coli NAR analysis in tile drain effluent from a mixed tree intercrop and monocrop system. Agric. Ecosyst. Environ. 131(1-2): 77-84.

Einarson, M.D., and J.A. Cherry. 2002. A new multilevel ground water monitoring system using multichannel tubing. Ground Water Monit. Remediat. 22(4): 52-65.

Environment Canada. 2013. Climate Trends and Variations Bulletin - Annual 2012. Available: http://www.ec.gc.ca/adsc-cmda/default.asp?lang=En\&n=77842065-1 [Accessed 3 May 2015].

EPA. 2002. Method 1604: Total Coliforms and Escherichia coli in Water by Membrane Filtration Using a Simultaneous Detection Technique (MI Medium).

Fallow, D., D. Brown, G. Parkin, J. Lauzon, and C. Wagner-Riddle. 2003. Land Resource Science Technical Memo No. 2003-1: Identification of Critical Regions for Water Quality Monitoring with Respect to Seasonal and Annual Water Surplus. Available: http://hdl.handle.net/10214/2204 [Accessed 26 April 2015].

Freeze, R.A., and J.A. Cherry. 1979. Groundwater. Prentice Hall, Englewood Cliffs, NJ.

Gagliardi, J. V, and J.S. Karns. 2000. Leaching of Escherichia coli 0157:H7 in diverse soils under various agricultural management practices. Appl. Environ. Microbiol. 66(3): 877-83.

Gallagher, M.A. 2012. Growth kinetics of wildlife E. coli isolates in soil and water. J. Environ. Prot. (Irvine,. Calif). 03(28): 838-846.

Gartner Lee. 2004. Guelph/Eramosa Township Regional Groundwater Characterization and Wellhead Protection Study. Prepared for the Township of Guelph/Eramosa and Ontario Ministry of the Environment.

Gerber, R., J. Boyce, and K. Howard. 2001. Evaluation of heterogeneity and field-scale groundwater flow regime in a leaky till aquitard. Hydrogeol. J. 9(1): 60-78.

Gerke, H.H., S. Koszinski, T. Kalettka, and M. Sommer. 2010. Structures and hydrologic function of soil landscapes with kettle holes using an integrated hydropedological approach. J. Hydrol. 393(1-2): 123-132.

Goss, M., D. Barry, and D. Rudolph. 1998. Contamination in Ontario farmstead domestic wells and its association with agriculture: 1. Results from drinking water wells. J. Contam. Hydrol. 32: 267-293.

Harrar, W.G., L.C. Murdoch, B. Nilsson, and K.E.S. Klint. 2007. Field characterization of vertical bromide transport in a fractured glacial till. Hydrogeol. J. 15(8): 1473-1488. 
Harter, T., H. Davis, M.C. Mathews, and R.D. Meyer. 2002. Shallow groundwater quality on dairy farms with irrigated forage crops. J. Contam. Hydrol. 55(3-4): 287-315.

Hrudey, S.E., P. Payment, P.M. Huck, R.W. Gillham, and E.J. Hrudey. 2003. A fatal waterborne disease epidemic in Walkerton, Ontario: Comparison with other waterborne outbreaks in the developed world. Water Sci. Technol. 47: 7-14.

Ishii, S., W.B. Ksoll, R.E. Hicks, and M.J. Sadowsky. 2006. Presence and growth of naturalized Escherichia coli in temperate soils from Lake Superior watersheds. Appl. Environ. Microbiol. 72(1): 612-621.

Iversen, B. V, P. van der Keur, and H. Vosgerau. 2008. Hydrogeological relationships of sandy deposits: modeling of two-dimensional unsaturated water and pesticide transport. J. Environ. Qual. 37(5): 1909-1917.

Jarvis, N.J. 2007. A review of non-equilibrium water flow and solute transport in soil macropores: principles, controlling factors and consequences for water quality. Eur. J. Soil Sci. 58(3): 523-546.

Karrow, P. 1968. Pleistocene Geology of the Guelph Area, Southern Ontario. Geological Report 61. Ontario Department of Mines.

Karrow, P. 1987. Quaternary Geology of the Hamilton-Cambridge Area. Ontario Geological Survey Report 255. Ministry of Northern Development and Mines.

Kozuskanich, J., K.S. Novakowski, and B.C. Anderson. 2011. Fecal indicator bacteria variability in samples pumped from monitoring wells. Ground Water 49(1): 43-52.

Kroetsch, D., and C. Wang. 2008. Particle Size Distribution. p. 713-725. In Carter, M.R., Gregorich, E.G. (eds.), Soil Sampling and Methods of Analysis. 2nd ed. Taylor \& Francis, Boca Raton.

Lang, N.L., and S.R. Smith. 2007. Influence of soil type, moisture content and biosolids application on the fate of Escherichia coli in agricultural soil under controlled laboratory conditions. J. Appl. Microbiol. 103(6): 2122-31.

LeChevallier, M.W., and G.A. McFeters. 1985. Interactions between heterotrophic plate count bacteria and coliform organisms. Appl. Environ. Microbiol. 49(5): 1338-41.

Levison, J., and K. Novakowski. 2009. The impact of cattle pasturing on groundwater quality in bedrock aquifers having minimal overburden. Hydrogeol. J. 17(3): 559-569.

Mckay, L., J.A. Cherry, R.C. Bales, M.T. Yahya, and C.P. Gerba. 1993. A field example of bacteriophage as tracers of fracture flow. Environ. Sci. Technol. 27(6): 1075-1079.

Meriano, M., and N. Eyles. 2003. Groundwater flow through Pleistocene glacial deposits in the rapidly urbanizing Rouge River - Highland Creek watershed, City of Scarborough, southern Ontario, Canada. Hydrogeol. J. 11(2): 288-303. 
Oliver, D.M., L. Heathwaite, P.M. Haygarth, and C.D. Clegg. 2005. Transfer of Escherichia coli to water from drained and undrained grassland after grazing. J. Environ. Qual. 34(3): 918-25.

Opazo Gonzalez, T. 2012. Evaluation of Sources and Processes Controlling Groundwater Nitrate in a Silurian Bedrock Aquifer. M.Sc. thesis, University of Waterloo.

Packard Instrument Company Inc. 1986. Tri Carb Liquid Scintillation Analyzer Model 1500 Operation Manual. Rev. A, Publication No. 169-3059.

Presant, E., and R. Wicklund. 1971. The Soils of Waterloo County. Report 44 of the Ontario Soil Survey. Research Branch, Canada Department of Agriculture.

Quinn, P.M., B.L. Parker, and J. a. Cherry. 2011. Using constant head step tests to determine hydraulic apertures in fractured rock. J. Contam. Hydrol. 126(1-2): 85-99.

R Development Core Team. 2014. R: A language and environment for statistical computing (version 3.1.2) [computer software]. R Foundation for Statistical Computing, Vienna, Austria.

RStudio. 2014. RStudio: Integrated development environment for R (Version 0.98.1091) [computer software]. RStudio, Boston.

Ruland, W.W., J.A. Cherry, and S. Feenstra. 1989. The depth of fractures and active ground-water flow in a clayey till plain in Southwestern Ontario. Ground Water 29(3): 405-417.

Sadura, S., I.P. Martini, A.L. Endres, and K. Wolf. 2006. Morphology and GPR stratigraphy of a frontal part of an end moraine of the Laurentide Ice Sheet: Paris Moraine near Guelph, ON, Canada. Geomorphology 75(1-2): 212-225.

Samarajeewa, A.D., S.M. Glasauer, J.D. Lauzon, I.P. O'Halloran, G.W. Parkin, and K.E. Dunfield. 2012. Bacterial contamination of tile drainage water and shallow groundwater under different application methods of liquid swine manure. Can. J. Microbiol. 58: 668-677.

Saxton, K.E. 2007. SPAW (Soil-Plant-Air-Water) Field \& Pond Hydrology v. 6.02 [software]. Available: http://hrsl.ba.ars.usda.gov/SPAW/Index.htm [Accessed 26 April 2015].

Saxton, K.E., and W.J. Rawls. 2006. Soil water characteristic estimates by texture and organic matter for hydrologic solutions. Soil Sci. Soc. Am. J. 70(5): 1569-1578.

Saxton, K., and P. Willey. 2005. The SPAW Model for Agricultural Field and Pond Hydrologic Simulation. In Singh, V., Frevent, D. (eds.), Mathematical Modeling of Watershed Hydrology. CRC Press LLC.

Schuh, W., R. Meyer, M. Sweeney, and J. Gardner. 1993. Spatial variation of root-zone and shallow vadose-zone drainage on a loamy glacial till in a sub-humid climate. J. Hydrol. 148: 1-26.

Sminchak, J.R., D.F. Dominic, and R.W. Ritzi. 1996. Indicator geostatistical analysis of sand interconnections within a till. Ground Water 34(6): 1125-1131. 
Somarelli, J.A., J.C. Makarewicz, R. Sia, and R. Simon. 2007. Wildlife identified as major source of Escherichia coli in agriculturally dominated watersheds by BOX A1R-derived genetic fingerprints. J. Environ. Manage. 82(1): 60-5.

SWOOP. 2006. Southwestern Ontario Orthoimagery Project. Orthoimagery Tiled Dataset [digital imagery]. Ontario Ministry of Natural Resources.

Taylor, C. 1977. Tritium enrichment of environmental waters by electrolysis: development of cathodes exhibiting high isotopic separation and precise measurement of tritium enrichment factors. p. 13140. In Proceedings of the International Conference of Low-Radioactivity Measurements and Applications, Slovenski Pedagogicke Nakladatelstvo, Bratislava.

Technical Experts Committee. 2004. Watershed-based source protection planning: Science-based decision-making for protecting Ontario's drinking water resources: A threats assessment framework. Report to the Minister of the Environment. Queen's Printer for Ontario. Available: http://www.sourcewater.ca/SWP_Resources/swp_background_technical.pdf [Access 26 April 2015].

Unc, A. 1999. Transport of Faecal Bacteria From Manure Through the Vadose Zone. M.Sc. thesis, University of Guelph.

Unc, A., and M.J. Goss. 2003. Movement of faecal bacteria through the vadose zone. Water. Air. Soil Pollut. 149: 327-337.

Unc, A., and M. Goss. 2004. Transport of bacteria from manure and protection of water resources. Appl. Soil Ecol. 25(1): 1-18.

Vanderzaag, A.C., K.J. Campbell, R.C. Jamieson, A.C. Sinclair, and L.G. Hynes. 2010. Survival of Escherichia coli in agricultural soil and presence in tile drainage and shallow groundwater. Can. J. Soil Sci. 90: 495-505.

Wagner-Riddle, C., and G.W. Thurtell. 1998. Nitrous oxide emissions from agricultural fields during winter and spring thaw as affected by management practices. J. Sustain. Agric. 52(2-3): 151-163.

Zaleski, K.J., K.L. Josephson, C.P. Gerba, and I.L. Pepper. 2005. Survival, growth, and regrowth of enteric indicator and pathogenic bacteria in biosolids, compost, soil, and land applied biosolids. J. Residuals Sci. Technol. 2(1): 49-63. 


\section{Figure captions}

Fig. 1: Map of the Arkell Research Station study area. Map created using ESRI ArcMap 10.1 with estimated water table based on data in (Opazo Gonzalez, 2012) and satellite imagery from (SWOOP, 2006). Note the relatively level outwash plain in the north and west and the higher-relief moraine in the south and east, indicated by more common forested areas. GPR $=$ ground-penetrating radar. masl $=$ metres above sea level.

Fig. 2: Geologic data from the ARS-1A core. a. Port locations; b. geologic log showing dominant lithologies; c. grain size distribution of the matrix determined by laboratory sieving and hydrometer analysis (Kroetsch and Wang, 2008), and total gravel content (estimated visually in the field). Hydraulic conductivity $\left(\mathrm{K}_{\text {sat }}\right)$ estimates using matrix sand/silt/clay fractions were calculated using the SPAW Soil Water Characteristics Calculator (Saxton and Willey, 2005; Saxton and Rawls, 2006; Saxton, 2007); d. field photos of dominant lithologies. Location of horizontal fractures and one short vertical fracture with iron oxide staining is shown on log. The upper section of dolostone was pulverized by the rotosonic drilling and so natural fractures could not be observed.

Fig. 3: Geologic cross-section through the Arkell Research Station (see Fig. 1 for location), using the recovered core for this study and cuttings recovered during piezometer installation in the 1980s (unpublished data, H.R. Whiteley, 2013). Vertical exaggeration is $25 x$. m.a.s.I. = metres above sea level.

Fig. 4: a. Precipitation and water elevations in the ARS-1A well over the study period. Precipitation data was obtained from the Guelph Turfgrass Institute weather station maintained by Environment Canada ( $<5 \mathrm{~km}$ from the study site) (Agricultural and Forest Meteorology Group, 2012). The hatched bar indicates both the timing and equivalent volume of the liquid swine manure application. b. E. coli concentrations in well samples. Error bars indicate the standard error of the mean of replicates for each sample (some error bars are covered by the data point). The dashed line indicates timing of the manure 
application. Values of $300 \mathrm{CFU} / 100 \mathrm{ml}$ are above the upper detection limit. m.a.s.I. = metres above sea level. $\mathrm{CFU}=$ colony-forming units.

Fig. 5: Conceptual diagram of the study site. a. Manure treatment area (1.6 ha, $210 \times 75 \mathrm{~m} ; 115 \mathrm{~m}$ between ARS-1A and the outer edge of the field in the upgradient groundwater flow direction) within field A5 ( 32 ha, $900 \times 350$ m); tortuous infiltration pathways through unsaturated sediments and fracture flow in bedrock. Preferential paths include 1) macropores in soil; 2) sediment heterogeneity and discontinuous basal diamict; 3) fractures in finer grained sediment (diamict or mud); 4) depression focused recharge; 5) fractures in bedrock; b. context of study area (not to scale) showing multilevel monitoring well ARS-1A capturing shallow flow paths originating on outwash plain (5.5 - $54 \mathrm{~m}$ ) and groundwater originating from agricultural areas on the Paris moraine (900 m) captured in deeper regional aquifer. 


\section{Tables}

Table 1: E. coli and total coliform concentration in samples of soil and liquid swine manure. Soil numbers are indicative of conditions prior to the April 9, 2012 manure application.

\begin{tabular}{|c|c|c|c|c|c|}
\hline & \multicolumn{2}{|r|}{ E. coli } & \multirow[b]{2}{*}{ Std. error } & \multicolumn{2}{|c|}{ Total Coliforms (not including E. coli) } \\
\hline & $\mathbf{n}$ & Mean & & Mean & Std. error \\
\hline Soil & & $3.8 \times 10^{3} \mathrm{CFU} / \mathrm{g}$ & $8.9 \times 10^{2} \mathrm{CFU} / \mathrm{g}$ & $4.6 \times 10^{3} \mathrm{CFU} / \mathrm{g}$ & $1.7 \times 10^{3} \mathrm{CFU} / \mathrm{g}$ \\
\hline (8-Apr-2012) & 3 & $2.25 \times 10^{6} \mathrm{CFU} / 100 \mathrm{ml}$ & $5.3 \times 10^{5} \mathrm{CFU} / 100 \mathrm{ml}$ & $2.7 \times 10^{6} \mathrm{CFU} / 100 \mathrm{ml}$ & $1.0 \times 10^{6} \mathrm{CFU} / 100 \mathrm{ml}$ \\
\hline Liquid Manure & 3 & $4.6 \times 10^{4} \mathrm{CFU} / 100 \mathrm{ml}$ & $1.1 \times 10^{4} \mathrm{CFU} / 100 \mathrm{ml}$ & $6.6 \times 10^{4} \mathrm{CFU} / 100 \mathrm{ml}$ & $1.4 \times 10^{4} \mathrm{CFU} / 100 \mathrm{ml}$ \\
\hline (9-Apr-2012) & & $6.4 \times 10^{4} \mathrm{CFU} / \mathrm{g}$ & $1.5 \times 10^{4} \mathrm{CFU} / \mathrm{g}$ & $9.3 \times 10^{4} \mathrm{CFU} / \mathrm{g}$ & $1.9 \times 10^{4} \mathrm{CFU} / \mathrm{g}$ \\
\hline
\end{tabular}

CFU = colony forming units. CFU/g is based on dry weight. CFU/100ml for the soil samples provides a porewater equivalent concentration assuming that all E.coli or total coliforms in the soil were mobilized into its porewater and that the volumetric moisture content of the soil is $24 \%$. 


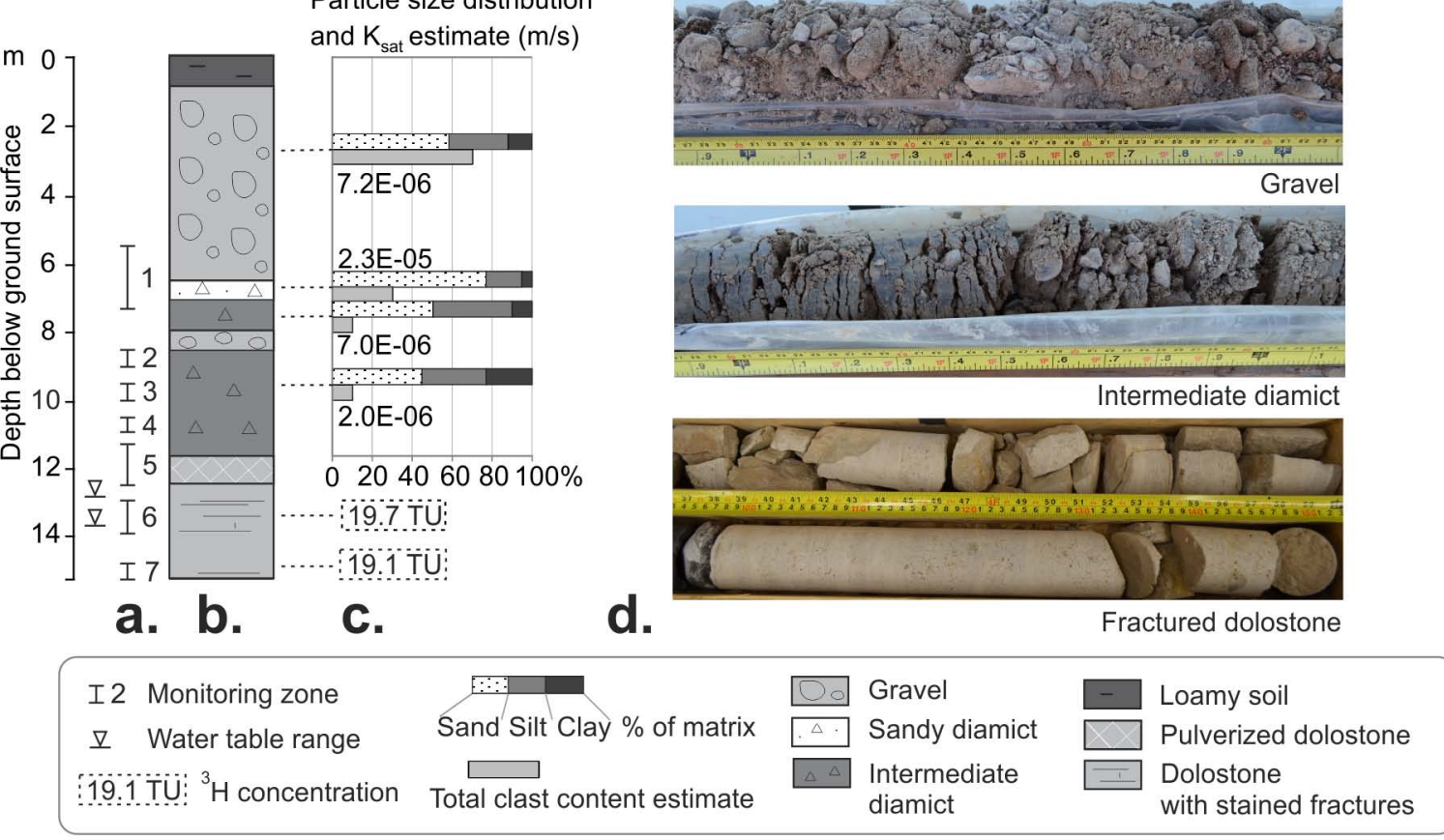

Arnaud et al. - JEQ-2015-02-0067-MTF.R1; Transport of Escherichia coli through a thick vadose zone, Fig. 2 


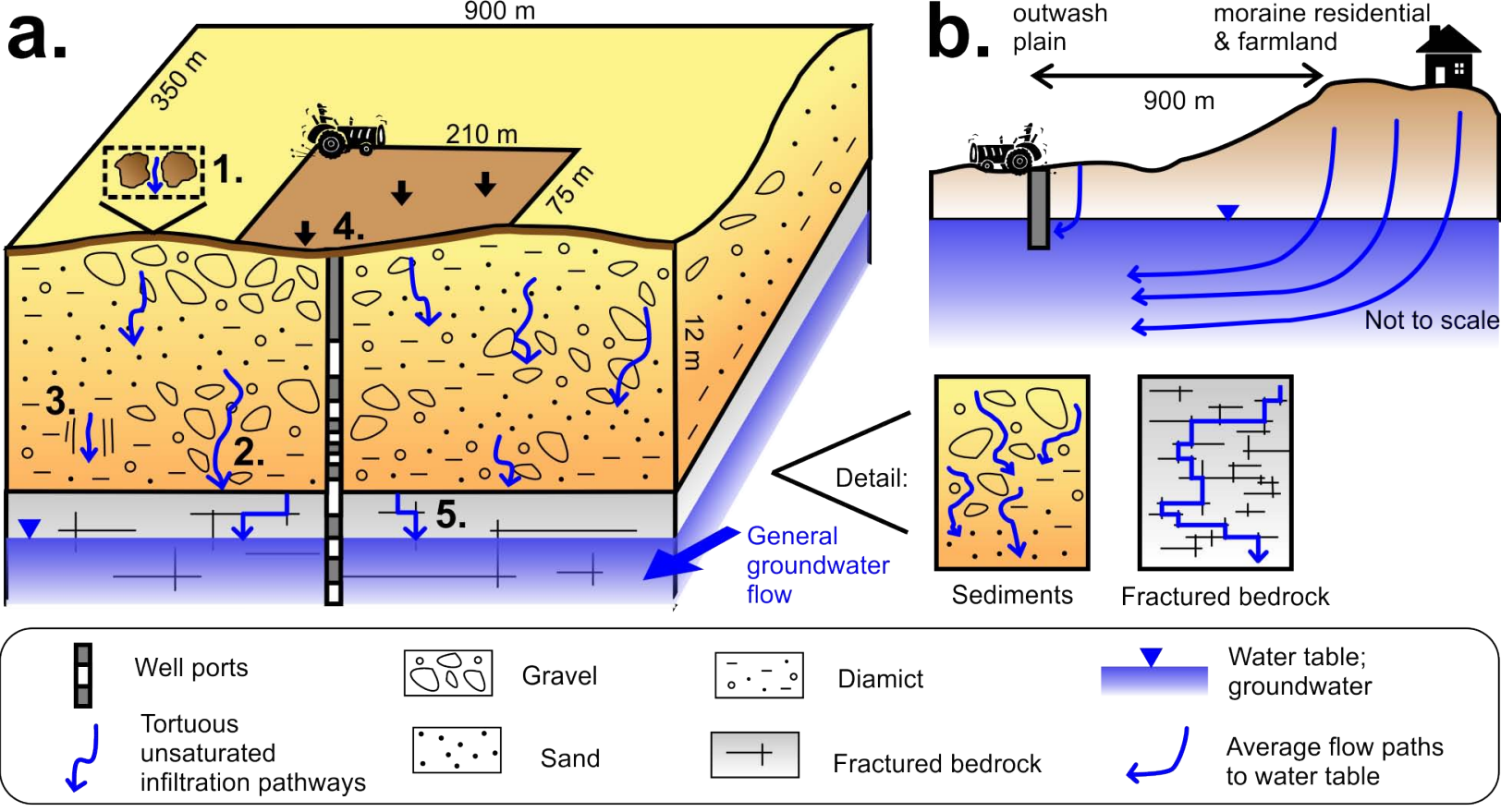

Arnaud et al. - JEQ-2015-02-0067-MTF.R1; Transport of Escherichia coli through a thick vadose zone, Fig. 5 


\section{Transport of Escherichia coli through a thick vadose zone}

Anna Best, Emmanuelle Arnaud, Beth Parker, Ramon Aravena, Kari Dunfield

Number of pages: 1

Number of Supplemental Figures: 1 

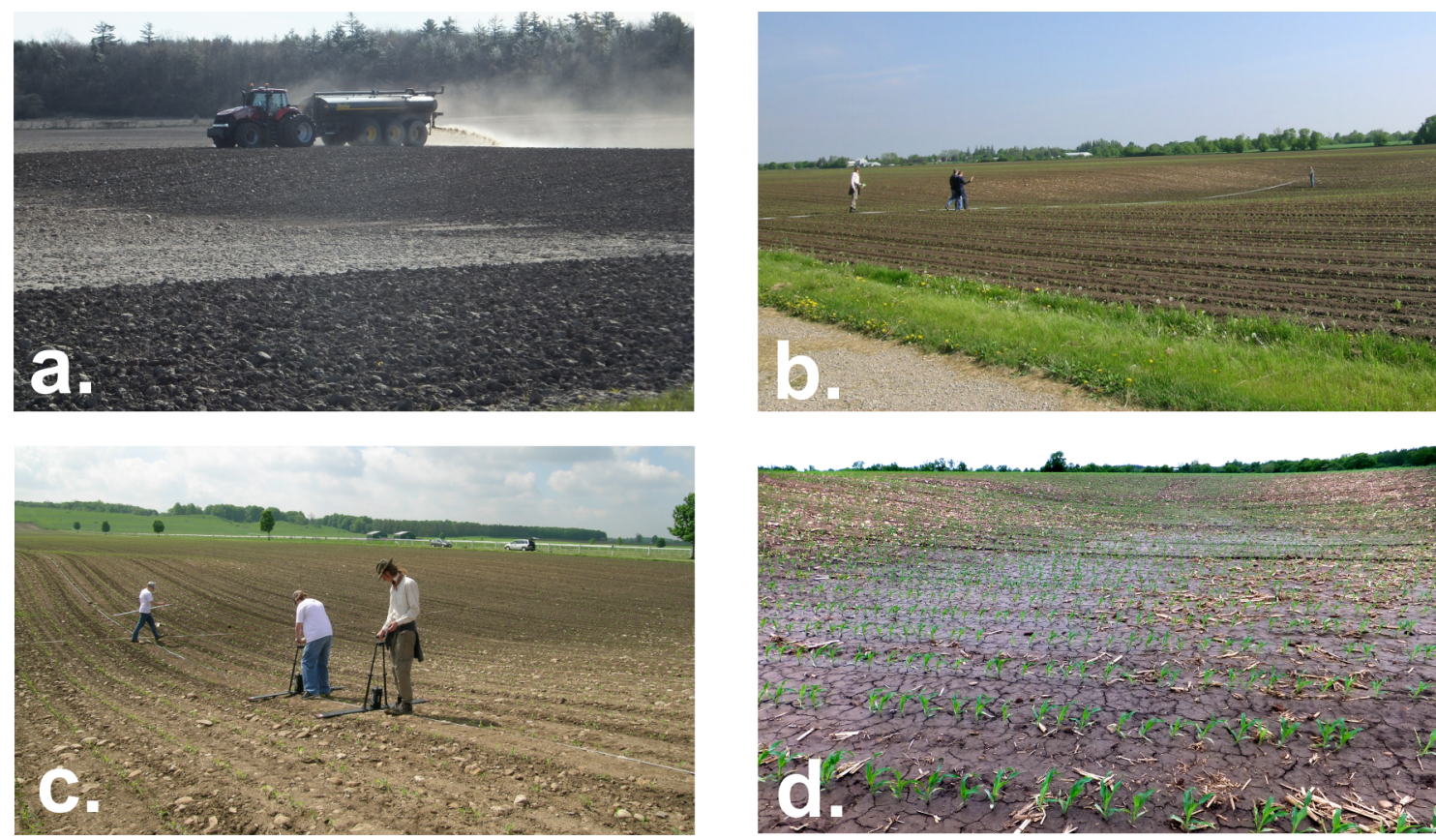

Best et al. - Transport of Escherichia coli through a thick vadose zone

Fig. S1: Photos showing the topography in field A5. a. Manure application on rolling topography (looking east); b. Most notable depression in field A5, at the northwest edge of the April 2012 manure application area (looking northeast); c. View from inside depression (looking southeast towards the Paris Moraine); $d$. view from inside lowest part of depression after wet weather, showing mudcracks and damp soil (looking east). 